\title{
DECOMPOSITION OF PRODUCTIVITY AND UNIT COSTS
}

\author{
L. Slifman and C. Corrado* \\ Board of Governors of the \\ Federal Reserve System
}

November 18, 1996

* Associate Director, Division of Research and Statistics, and Chief, Industrial Output Section, Division of Research and Statistics. Other Federal Reserve staff contributors to this report were Mark Doms, Charles Fleischman, Gloria Fennell, Marc Fusaro, Fong Kiang, Elizabeth Vrankovich, and Beth Anne Wilson. The authors thank Robert Parker and Gerald Donahoe of the Bureau of Economic Analysis for providing unpublished income estimates, and Alan Greenspan, Alice Rivlin, David Stockton, P. A. Tinsley, and Ellen Dykes of the Federal Reserve Board as well as Edwin Dean (BLS), Michael Harper (BLS), Steven Landefeld (BEA), and Robert Parker (BEA) for helpful comments on an earlier draft. This paper does not necessarily reflect the views or opinions of the Board of Governors of the Federal Reserve System. 


\title{
DECOMPOSITION OF PRODUCTIVITY AND UNIT COSTS
}

\author{
L. Slifman and C. Corrado
}

Labor productivity (output per hour) in the private business sector is reported to have been rising at an annual rate of about 1-1/4 percent since 1973. At the same time, output per hour in the nonfinancial corporate sector is estimated to have been increasing at a 1-3/4 percent annual rate. Given that the nonfinancial corporate sector is about two-thirds of the aggregate, these statistics imply that output per hour elsewhere in private business has not increased, on average, for more than two decades.

For the past fifteen years, productivity growth in manufacturing has been relatively robust. A BLS study concluded that all of the growth in private business multifactor productivity in the 1980s could be attributed to manufacturing. ${ }^{1}$ Moreover, the published figures for private business and manufacturing labor productivity suggest that since the beginning of the 1990s output per hour in the nonmanufacturing sector of the economy has been disappointing.

Because it seems unlikely that major sectors of the economy have, in reality, failed to become more efficient year in and year out, it would be useful to try to identify at a more disaggregated level those segments of the economy with persistently dismal measured productivity performance. Moreover, for purposes of current analysis, one would like to have the data at a quarterly frequency. This paper presents such a disaggregation. The decompositions are by legal form of organization, with gross industry breaks within the corporate sector, and by detailed industry. For expository convenience, we refer to the former as the "sectoral" decomposition and the latter as the "industry" decomposition. An accompanying dataset contains the complete set of sectoral and industry estimates of labor productivity as well as a decomposition of sectoral data on unit costs and profits.

\section{Decomposition of Productivity and Unit Costs by Sector}

The sectoral decomposition develops product and income accounts for subsectors of the domestic business sector in the national income and product accounts (NIPAs). The basic idea underlying the decomposition is that the Commerce Department's Bureau of Economic Analysis (BEA) publishes quarterly income and product for the domestic business sector and for most of the corporate business sector. The BEA also publishes annual income and product for farms and owner-occupied housing. After making a few interpolations (and extrapolations) of these annual data, as well as constructing an implicit deflator for the output of financial corporations, one can calculate a complete quarterly income and product account for the nonfarm business

\footnotetext{
${ }^{1}$ William Gullickson, "Multifactor Productivity in Manufacturing Industries," Monthly Labor Review (October 1992); see especially page 29 and chart 2.
} 
sector (as defined by BLS for official productivity estimates). ${ }^{2}$ An income and product account for the noncorporate sector can then be calculated as a residual. The nonfarm, nonfinancial corporate sector is further disaggregated into manufacturing and nonmanufacturing; this disaggregation relies, in part, on BEA's annual series on gross product originating by industry (see below). A complete description of all the series that are part of the sectoral decomposition appears in Appendix 1.

\section{What Does the Decomposition Comprise?}

The sectoral decomposition breaks the nonfarm business sector (less housing) into the following sectors: nonfarm corporate business, financial corporations, nonfarm nonfinancial corporations, manufacturing corporations, nonmanufacturing corporations (excluding farm and financial corporations), and nonfarm noncorporations. The nonfarm noncorporate sector consists primarily of sole proprietorships and partnerships, with nearly half of the sector's income generated by businesses in the services industry. ${ }^{3}$ In addition, nominal and real product for the total nonfarm business sector and for the nonfarm noncorporate business sector are recalculated on an "income basis" by subtracting the NIPA statistical discrepancy. Because the statistical discrepancy has swung from $+\$ 58$ billion in 1993 to $-\$ 51$ billion in 1996:Q2, the income-based measures of activity (and, hence, productivity) have been growing more rapidly than the output-based numbers in recent quarters.

Each sector is decomposed into the following product and income components: nominal gross product; real gross product; consumption of fixed capital (with capital consumption adjustment); indirect business taxes, business transfers, and net subsidies; compensation; profits (with inventory valuation adjustment and capital consumption adjustment); net interest; proprietors' income; and rental income.

When real sector product is divided by hours worked, the result is labor productivity, or output per hour. ${ }^{4}$ When nominal sector product and its income components are divided by real sector product, the result is a complete unit cost (and profit) accounting that adds up to the implicit deflator for the sector. The unit cost decomposition for each sector is presented in the accompanying dataset.

${ }^{2}$ The interpolations, extrapolations, and data constructions are based primarily on published quarterly NIPA series and are described in Appendix 1.

${ }^{3}$ The services industry share reflects calculations based on unpublished BEA data on domestic income by industry and legal form of business. See table 4, line 15, column 3 .

${ }^{4}$ Note that the manufacturing sectoral real product estimates presented here are value-added measures and thus differ from sectoral output as calculated by BLS. See William Gullickson, "Measurement of Productivity Growth in U.S. Manufacturing," Monthly Labor Review (July 1995), pp. 13-28. 


\section{Highlights of the Sectoral Decomposition}

Tables 1 and 2 summarize the results of the exercise. The upper portion of table 1 shows the annualized growth rate of real sector output over selected time periods and the next portion shows the corresponding growth rates of hours worked. ${ }^{5}$ The third and fourth sections show labor productivity (output per hour) and unit labor costs by sector. As can be seen in line 16, the official measure of labor productivity in the nonfarm business sector slowed from an annual growth rate of 2.8 percent in the 1960 s and early 1970 s to a 0.9 percent rate during the 1990 s. Even when measured on an income basis (line 17), the recent performance (1.2 percent per year) has been disappointing compared with that in the 1960s.

By sector, the decomposition suggests that the 1970s slowdown in measured productivity growth was concentrated in the corporate manufacturing and nonfarm noncorporate sectors (lines 21 and 23). Subsequently, output per hour in manufacturing recovered. But the level of output in the noncorporate sector, as implied by this decomposition, has continued to fall. Table 2 provides perspective on the relative size of each sector's domestic income, real output, and hours. As may be seen, the nonfarm noncorporate sector has accounted for just under one-fourth of nonfarm business activity in recent years.

Accompanying the lackluster behavior of productivity in the nonfarm noncorporate sector has been rapid growth in unit labor costs compared with those in the corporate sector (table 1 , line 31 vs. line 26). At the same time, as shown in chart 1 , the return to the owners of nonfarm noncorporate businesses (that is, proprietors' income plus rental income) as a share of either nominal gross sector product or domestic income has been well maintained in recent years. ${ }^{6}$ Consequently, as illustrated by chart 2 , since 1976 the implicit deflator for the nonfarm noncorporate sector has been rising much faster than the deflator for the nonfarm corporate sector -- 6.7 percent (annual rate) vs. 4 percent (annual rate).

\section{A Caveat}

A critical component of this decomposition is BEA's estimate of real nonfinancial corporate output. To calculate real nonfinancial corporate output, BEA deflates current-dollar nonfinancial corporate product using the implicit deflator for goods and structures, which may not accurately represent corporate product prices. For example, corporate product includes almost all of the output for services, such as purchased

\footnotetext{
${ }^{5}$ For the most part, the figures on hours worked are those used in the BLS measures of output per hour for nonfarm business, nonfinancial corporations, and manufacturing. See Appendix 1 for a complete description.

${ }^{6}$ The domestic income of a sector is equal to the sector's gross product originating minus the consumption of fixed capital, indirect business taxes, and business transfers, plus net subsidies. See table A-1, line 6.
} 
intercity transportation, household utilities, and motion pictures, as well as a portion of legal services. However, the quantity weights for the prices of these and other obviously excluded categories are relatively small for the nonfinancial corporate sector as a whole (see table 4, column 2).

In fact, as shown on chart 3, a nonfinancial corporate output price index constructed to reflect the two-digit industry composition of nonfinancial corporate product does not show a long-term trend that is significantly different from BEA's published deflator. The broad trends implied by the productivity and unit cost decompositions, which are based on the published estimates of real nonfinancial corporate product, would be little changed if current-dollar nonfinancial corporate product were deflated with the constructed price index. However, the chart does show the two deflators beginning to diverge in the 1990s, suggesting that in recent years the use of official statistics for the decomposition has caused a misallocation of a small portion of real product from the noncorporate sector to the nonmanufacturing corporate sector.

\section{Decomposition of Productivity by Industry}

The industry decomposition relies on one- and two-digit SIC industry output, employment, and hours data that are available as part of BEA's gross product by industry dataset. ${ }^{7}$ An important caveat associated with using these data for longer-run historical comparisons is that the SIC system was changed in 1987. BEA's recommendations have been followed in combining certain two-digit industries to create reasonably continuous time series. ${ }^{8}$ In any event, with these data, output per hour measures were calculated for detailed industries and aggregated to a measure for the nonfarm business sector less housing. ${ }^{9}$

\section{Highlights of the Industry Decomposition}

Table 3 summarizes the results of this exercise. As can be seen by comparing lines 1 and 2, growth rates of the constructed aggregate and the official series are quite close,

\footnotetext{
${ }^{7}$ This decomposition is similar to analyses of output per hour by major industry presented in the 1988 Economic Report of the President, page 73, and in Zvi Griliches' introduction to the conference volume Output Measurement in the Service Sectors, University of Chicago Press, 1992, page 5. In addition to updating these earlier studies, this report presents productivity estimates at a more disaggregated level.

${ }^{8}$ See the August 1996 edition of the Survey of Current Business for a complete description of gross product by industry and BEA's recommendations for linking the data across the 1987 SIC change.

${ }^{9}$ Unlike the official BLS productivity series, the constructed aggregate includes output and hours from nonprofit institutions and paid private household workers. In addition, the constructed series excludes the entire government, and agriculture, forestry, and fishing industries rather than just excluding farm output and hours.
} 
even though 25 percent of services industry domestic income is not in the business sector (table 5, column 3, line 15). Within the industry decomposition, the results are similar to those in the sectoral decomposition--that is, the level of measured output per hour in the services industry (line 16) has been falling continuously for the past two decades. Lines 17 to 28 provide additional detail and suggest that the disappointing reported productivity performance has been widespread across nearly all two-digit services industries.

\section{Questions Raised by the Decomposition}

As indicated above, the dataset shows that the profitability of noncorporate businesses, (proxied by proprietors' income plus rental income as a share of sector output) has been well maintained in the face of declining productivity over the past two decades. One question raised by the decomposition, then, is, Does such a confluence of events make economic sense? It seems unlikely that firms with declining long-term productivity would be able to avoid bankruptcy let alone maintain the rate of return to the owners. In theory, some firms could have low or declining measured output per hour and still be profitable, but it is hard to imagine this occurring on a widespread basis. To be sure, the noncorporate sector is not stagnant; it reflects many start-up businesses, the most successful of which eventually incorporate. But the confluence of events as described by this dataset requires the sector to have persistently harbored the economy's least efficient businesses since the mid-1970s, which seems inconsistent with the sector's continued profitability.

In an accounting sense, these apparently incompatible productivity and profitability trends can be reconciled by relatively rapid increases in the prices of the noncorporate sector's output. Is there an economic explanation for the rapid rise over two decades in the relative price of output from the noncorporate sector? Factors such as widespread price inelastic demand, barriers to entry, including nontransferable intellectual property rights, and so forth could possibly explain such trends. But it is hard to imagine the presence of these factors on a wide enough scale to account for a significant portion of the productivity slowdown in the noncorporate sector.

Alternatively, the sector's measured trends in productivity, profitability, and prices may not reflect actual economic developments. Thus, another question raised by the decomposition is, Do these inconsistent trends signify problems with our economic statistics?

One possible measurement problem is that nominal output could be understated. In particular, the invoices for some output may not be captured by the Commerce Department's statistical nets. But is the problem, if it exists, getting worse? The $\$ 100$ billion swing in the statistical discrepancy since 1993 does raise the possibility that nominal output growth has been understated in recent years. Nevertheless, the income-based measures of output per hour presented on lines 17 and 23 of table 1 suggests that mismeasurement of nominal output is unlikely to account for much of 
the dreary performance of productivity as indicated by published statistics over the past two decades.

A more likely statistical explanation for the implausible productivity, profitability, and price trends in the noncorporate sector is that they reflect problems in measuring prices. Indeed, the decomposition of national accounts data presented here can be viewed as providing a macroeconomic perspective on the problems of price measurement that many other researchers have noted from a microstatistical perspective. $^{10}$ It suggests that actual inflation in the economy is less than that shown by the published data, and, accordingly, actual growth of output and productivity is faster.

What is the possible magnitude of the overstatement of inflation that emerges from this dataset? As a benchmark thought experiment for making a judgment on this issue, one could assume that instead of falling for the past two decades, productivity in all declining two-digit service-producing industries has been flat. Such a calculation suggests that over the past two decades aggregate productivity growth would have been nearly half a percentage point faster per year than indicated by the published data and, that for a given nominal output, inflation would have been lower by the same amount. ${ }^{11}$ This benchmark figure, which is derived independently, is within the range of estimates of CPI biases arising from the slow introduction of new products and deficiencies of quality adjustment that have been noted by many researchers (see footnote 10). Of course, one could argue that even the assumption of no productivity growth for these industries is unrealistic. Obviously, if one were to assume that productivity in these industries has actually been improving, aggregate output per hour would rise even faster and price inflation would be still lower.

\section{A Concluding Thought}

\footnotetext{
${ }^{10}$ See, for example, the following studies: David E. Lebow, John M. Roberts, and David J. Stockton, "Monetary Policy and the Price Level," Federal Reserve Board, August 1994. J. Peterson, "Is the Growth of the CPI a Biased Measure of Changes in the Cost of Living?", Congressional Budget Office, 1994. Advisory Commission to Study the Consumer Price Index, "Toward a More Accurate Measure of the Cost of Living: Interim Report to the Senate Finance Committee," September 15, 1995. Mathew Shapiro and David W. Wilcox, "Mismeasurement in the Consumer Price Index: An Evaluation," NBER Working Paper 5590, May 1996.

${ }^{11}$ Seventeen industries were adjusted. Four of these industries were in the transportation sector: local and interurban passenger transit; trucking and warehousing; water transportation; and transportation services. Two of the adjusted industries were in finance, insurance, and real estate: insurance carriers; and insurance agents, brokers, and services. The remaining eleven adjusted were in the services industry: hotels and other lodging places; personal business services; business services; auto repair services and parking; miscellaneous repair services; motion pictures; amusement and recreation services; health services; legal services; education services; and social services.
} 
Many observers have questioned how the influence of relentless technological progress appears so prominently in statistics on manufacturing, but not in those for services. Some have long questioned the accuracy of the statistics themselves. ${ }^{12}$ Others suggest that the gains from new technologies take a long time to diffuse and that the productivity boost from information technology has yet to come. ${ }^{13}$ Yet others look more closely at structural developments such as "downsizing" and "outsourcing" and suggest that these need not stimulate aggregate growth or efficiency; instead, such developments could just reflect a reallocation of resources within the economy. Clearly, the basic trend toward automation in manufacturing and distribution will result in a productivity gain in the aggregate economy only if the laid-off workers find new jobs in which they are as productive as they were in their old jobs. If human capital is lost when production workers move from one industry to another following firm downsizing, aggregate labor productivity will not necessarily increase.

However, many of the changes in manufacturing over the 1980 s occurred as part of corporate restructuring that outsourced ancillary, labor-intensive, service activities of the basic enterprises. A related development is the increased tendency in the 1990s for manufacturers to purchase the services of temporary workers as labor on production lines. When a manufacturing or related enterprise decides to use temporary workers or to close down an ancillary activity (for example, a warehousing unit, a legal services department, or a research and development laboratory) and purchase the service on the market instead, value added in manufacturing is reduced and value added elsewhere in industry is increased. These changes reflect an alteration in the organization of production to meet a given pattern of final demand and do not necessarily result in an immediate increase in aggregate productive efficiency. Over time, however, contracting out ancillary activities means replacing own-account production by specialist production, which should eventually lead to an increase in productive efficiency for the economy as a whole. A final question, then, is How long does it take for these efficiency gains to occur, and when they do take place, will our economic statistics capture them?

\footnotetext{
${ }^{12}$ See, for example, Zvi Griliches, "Productivity, R\&D and the Data Constraint," American Economic Review (March 1994), pp. 1-23 and the references therein.

${ }^{13}$ Paul David, "The Dynamo and the Computer: An Historical Perspective on the Modern Productivity Paradox," American Economic Review: Papers and Proceedings (May 1990), and Nathan Rosenberg, "Uncertainty and Technological Change," unpublished paper prepared for a conference sponsored by the Federal Reserve Bank of Boston, June 5-7, 1996.
} 
Table 1

Sectoral Labor Productivity and Costs

(Percent change at an annual rate over period indicated)

\begin{tabular}{|c|c|c|c|c|c|c|}
\hline & & $\begin{array}{c}\text { 60:Q2 to } \\
96: Q 2\end{array}$ & $\begin{array}{c}\text { 60:Q2 to } \\
73: Q 4\end{array}$ & $\begin{array}{c}\text { 73:Q4 to } \\
80: Q 1\end{array}$ & $\begin{array}{c}80: Q 1 \text { to } \\
90: Q 2\end{array}$ & $\begin{array}{c}90: Q 2 \text { to } \\
96: Q 2\end{array}$ \\
\hline \multicolumn{7}{|c|}{ REAL OUTPUT } \\
\hline 1. & Nonfarm business sector & 3.3 & 4.5 & 3.0 & 2.9 & 2.1 \\
\hline 2. & Income-based & 3.3 & 4.4 & 2.6 & 3.0 & 2.3 \\
\hline 3. & Nonfarm corporate & 3.9 & 4.7 & 3.8 & 3.5 & 2.9 \\
\hline 4. & Financial & 3.5 & 3.2 & 7.4 & 1.7 & 3.2 \\
\hline 5. & Nonfinancial & 3.9 & 4.8 & 3.6 & 3.7 & 2.8 \\
\hline 6. & Manufacturing & 2.9 & 4.2 & 1.9 & 2.5 & 1.8 \\
\hline 7. & Nonmanufacturing & 4.6 & 5.4 & 4.8 & 4.3 & 3.3 \\
\hline 8. & Nonfarm noncorporate & 1.4 & 3.6 & -1.5 & 1.0 & 0.4 \\
\hline \multicolumn{7}{|c|}{ HOURS WORKED } \\
\hline 9. & Nonfarm business sector & 1.6 & 1.6 & 1.8 & 1.7 & 1.1 \\
\hline 10. & Nonfarm corporate & 2.2 & 2.9 & 2.2 & 1.8 & 1.2 \\
\hline 11. & Financial & 2.5 & 3.2 & 3.2 & 2.2 & 0.4 \\
\hline 12. & Nonfinancial & 2.2 & 2.9 & 2.1 & 1.8 & 1.3 \\
\hline 13. & Manufacturing & 0.3 & 1.4 & -0.1 & -0.5 & -0.4 \\
\hline 14. & Nonmanufacturing & 3.6 & 4.5 & 3.8 & 3.1 & 2.0 \\
\hline 15. & Nonfarm noncorporate & 0.2 & -1.1 & 0.5 & 1.5 & 0.9 \\
\hline \multicolumn{7}{|c|}{ LABOR PRODUCTIVITY } \\
\hline 16. & Nonfarm business sector & 1.7 & 2.8 & 1.2 & 1.1 & 0.9 \\
\hline 17. & Income-based & 1.7 & 2.8 & 0.9 & 1.2 & 1.2 \\
\hline 18. & Nonfarm corporate & 1.7 & 1.8 & 1.6 & 1.7 & 1.6 \\
\hline 19. & Financial & 1.0 & -0.0 & 4.1 & -0.5 & 2.8 \\
\hline 20. & Nonfinancial & 1.7 & 1.9 & 1.5 & 1.8 & 1.5 \\
\hline 21. & Manufacturing & 2.6 & 2.8 & 2.0 & 3.1 & 2.3 \\
\hline 22. & Nonmanufacturing & 1.0 & 0.9 & 1.0 & 1.2 & 1.2 \\
\hline 23. & Nonfarm noncorporate & 1.2 & 4.8 & -1.9 & -0.5 & -0.5 \\
\hline \multicolumn{7}{|c|}{ UNIT LABOR COSTS } \\
\hline 24. & Nonfarm business sector & 4.2 & 3.1 & 8.0 & 4.2 & 2.7 \\
\hline 25. & Income-based & 4.2 & 3.1 & 8.3 & 4.0 & 2.5 \\
\hline 26. & Nonfarm corporate & 3.8 & 3.3 & 7.3 & 3.5 & 1.9 \\
\hline 27. & Financial & 5.7 & 5.6 & 4.5 & 8.0 & 3.3 \\
\hline 28. & Nonfinancial & 3.7 & 3.2 & 7.5 & 3.2 & 1.8 \\
\hline 29. & Manufacturing & 3.1 & 2.4 & 7.8 & 2.2 & 1.6 \\
\hline 30. & Nonmanufacturing & 4.2 & 4.1 & 7.4 & 3.8 & 1.9 \\
\hline 31. & Nonfarm noncorporate & 4.8 & 1.0 & 11.0 & 6.2 & 5.0 \\
\hline
\end{tabular}


Table 2

Sectoral Income, Real Output and Hours (Average percentage of total nonfarm business over period indicated)

\begin{tabular}{|c|c|c|c|c|c|c|}
\hline & & $\begin{array}{c}1960 \text { to } \\
1995\end{array}$ & $\begin{array}{c}1960 \text { to } \\
1973\end{array}$ & $\begin{array}{c}1974 \text { to } \\
1979\end{array}$ & $\begin{array}{c}1979 \text { to } \\
1990\end{array}$ & $\begin{array}{c}1990 \text { to } \\
1995\end{array}$ \\
\hline \multicolumn{7}{|c|}{ DOMESTIC INCOME } \\
\hline 1. & Nonfarm business sector & 100.0 & 100.0 & 100.0 & 100.0 & 100.0 \\
\hline 2. & Nonfarm corporate & 76.7 & 74.8 & 77.8 & 78.2 & 77.4 \\
\hline 3. & Financial & 5.5 & 4.3 & 4.9 & 6.0 & 7.9 \\
\hline 4. & Nonfinancial & 71.2 & 70.5 & 73.0 & 72.2 & 69.5 \\
\hline 5. & Manufacturing & 29.9 & 34.6 & 31.4 & 26.6 & 23.0 \\
\hline 6. & Nonmanufacturing & 41.4 & 35.9 & 41.6 & 45.6 & 46.5 \\
\hline 7. & Nonfarm noncorporate & 23.3 & 25.2 & 22.2 & 21.8 & 22.6 \\
\hline \multicolumn{7}{|c|}{ REAL OUTPUT ${ }^{1}$} \\
\hline 8. & Nonfarm business sector & 100.0 & 100.0 & 100.0 & 100.0 & 100.0 \\
\hline 9. & Nonfarm corporate & 73.2 & 69.0 & 71.6 & 76.2 & 78.4 \\
\hline 10. & Financial & 7.5 & 6.8 & 7.6 & 8.2 & 7.6 \\
\hline 11. & Nonfinancial & 65.6 & 62.0 & 64.1 & 68.1 & 70.8 \\
\hline 12. & Manufacturing & 24.4 & 26.1 & 24.4 & 23.6 & 22.4 \\
\hline 13. & Nonmanufacturing & 41.1 & 35.6 & 39.7 & 44.6 & 48.4 \\
\hline 14. & Nonfarm noncorporate & 28.4 & 34.3 & 30.3 & 24.1 & 21.6 \\
\hline \multicolumn{7}{|c|}{ HOURS } \\
\hline 15. & Nonfarm business sector & 100.0 & 100.0 & 100.0 & 100.0 & 100.0 \\
\hline 16. & Nonfarm corporate & 72.7 & 67.9 & 74.5 & 76.2 & 76.3 \\
\hline 17. & Financial & 4.4 & 3.8 & 4.5 & 5.0 & 4.9 \\
\hline 18. & Nonfinancial & 68.3 & 64.1 & 70.0 & 71.2 & 71.4 \\
\hline 19. & Manufacturing & 28.2 & 32.7 & 29.5 & 25.1 & 21.7 \\
\hline 20. & Nonmanufacturing & 40.1 & 31.4 & 40.5 & 46.1 & 49.8 \\
\hline 21. & Nonfarm noncorporate & 27.3 & 32.1 & 25.5 & 23.8 & 23.7 \\
\hline
\end{tabular}

1. Figures for real output shares begin in 1961 and are relative to the income-based measure of total nonfarm business output. 


\section{Table 3}

Real Gross Product Originating per Hour, 1977-94

(Percent change at an annual rate over period indicated)

\begin{tabular}{|c|c|c|c|c|}
\hline & Industry & $\begin{array}{c}1977 \text { to } \\
1994\end{array}$ & $\begin{array}{c}1980 \text { to } \\
1990\end{array}$ & $\begin{array}{c}1990 \text { to } \\
1994\end{array}$ \\
\hline 1 & Nonfarm business sector, excluding housing (BLS) & 0.95 & 1.14 & 1.12 \\
\hline 2 & Nonagricultural private industries (exc. housing) & 0.89 & 1.17 & 1.03 \\
\hline 3 & Mining & 2.62 & 5.00 & 4.58 \\
\hline 4 & Construction & -1.02 & -0.68 & 0.77 \\
\hline 5 & Manufacturing & 2.45 & 3.22 & 2.15 \\
\hline 6 & Durables & 2.80 & 3.56 & 3.07 \\
\hline 7 & Nondurables & 1.99 & 2.73 & 0.96 \\
\hline 8 & Transportation and utilities & 1.51 & 1.29 & 2.58 \\
\hline 9 & Transportation & 0.58 & -0.05 & 2.34 \\
\hline 10 & Communications & 4.53 & 4.02 & 5.20 \\
\hline 11 & Public utilities & 0.65 & 1.21 & 2.80 \\
\hline 12 & Trade & 2.06 & 2.49 & 2.37 \\
\hline 13 & Wholesale trade & 3.30 & 3.34 & 5.42 \\
\hline 14 & Retail trade & 1.29 & 2.04 & 0.60 \\
\hline 15 & Finance, ins., real estate (exc. housing) & 0.16 & 0.10 & 0.88 \\
\hline 16 & Services & -0.56 & -0.50 & -1.11 \\
\hline 17 & Hotels and lodging & -1.53 & -1.46 & 0.40 \\
\hline 18 & Personal services & -0.87 & -0.53 & -0.71 \\
\hline 19 & Business and other services & -0.42 & -0.21 & -1.12 \\
\hline 20 & Auto repair & -1.26 & -1.04 & -1.87 \\
\hline 21 & Miscellaneous services & -0.20 & -1.22 & -3.47 \\
\hline 22 & Motion pictures & 1.65 & 1.68 & -1.05 \\
\hline 23 & Amusement services & 0.98 & 2.64 & -4.75 \\
\hline 24 & Health services & -1.84 & -1.82 & -2.50 \\
\hline 25 & Legal services & -2.77 & -2.58 & -3.61 \\
\hline 26 & Education services & 0.01 & -0.53 & 0.23 \\
\hline 27 & Membership orgs. and social services & -0.18 & -0.14 & 0.45 \\
\hline 28 & Private households & 2.16 & 3.70 & 2.07 \\
\hline
\end{tabular}

Notes: Hours of all persons in these calculations differ from hours of all persons as defined by the BLS because the calculations presented here include nonprofit institutions and private households. These calculations assume that selfemployed workers in each industry work the same number of hours annually as full-time wage and salary employees. 
Table 4

Distribution of Domestic Income across Private Nonagricultural Industries, by Legal Form of Organization, $1994^{1}$

\begin{tabular}{|c|c|c|c|c|c|}
\hline & & TOTAL & Corporations & $\begin{array}{c}\text { Sole } \\
\text { Proprietorships } \\
\text { and Partnerships }\end{array}$ & $\begin{array}{l}\text { Households } \\
\text { and Nonprofit } \\
\text { Institutions }\end{array}$ \\
\hline & Total & 100.00 & 100.00 & 100.00 & 100.00 \\
\hline 2. & Mining & 1.01 & 1.13 & 0.98 & 0.00 \\
\hline 3. & Construction & 5.98 & 5.69 & 10.68 & 0.00 \\
\hline 4. & Manufacturing & 23.78 & 30.43 & 5.26 & 0.23 \\
\hline 5. & Durables & 13.76 & 17.73 & 2.49 & 0.02 \\
\hline 6. & Nondurables & 10.02 & 12.69 & 2.77 & 0.20 \\
\hline 7. & Transportation and utilities & 10.37 & 11.83 & 7.06 & 3.83 \\
\hline 8. & Transportation & 4.59 & 5.04 & 3.24 & 3.22 \\
\hline 9. & Communications & 2.97 & 3.45 & 2.21 & 0.28 \\
\hline 10. & Public utilities & 2.80 & 3.35 & 1.60 & 0.32 \\
\hline 11. & Trade & 18.44 & 21.48 & 14.09 & 0.17 \\
\hline 12. & Wholesale trade & 7.59 & 9.36 & 3.36 & 0.08 \\
\hline 13. & Retail trade & 10.84 & 12.12 & 10.73 & 0.09 \\
\hline 14. & Finance, insurance, and real estate & 11.06 & 10.00 & 15.69 & 11.80 \\
\hline 15. & Services & 29.36 & 19.44 & 46.25 & 83.97 \\
\hline 16. & Hotels and lodging & 1.03 & 0.94 & 1.98 & 0.08 \\
\hline 17. & Personal services & 0.98 & 0.65 & 3.07 & 0.00 \\
\hline 18. & Motion pictures & 0.54 & 10.42 & 1.41 & 0.00 \\
\hline 19. & Amusement & 1.02 & 0.78 & 1.72 & 1.81 \\
\hline 20. & Business and other & 9.37 & 9.15 & 14.12 & 2.58 \\
\hline 21. & Auto repair & 0.92 & 0.73 & 2.35 & 0.00 \\
\hline 22. & Miscellaneous repair & 0.39 & 0.34 & 0.87 & 0.00 \\
\hline 23. & Health services & 9.39 & 4.69 & 11.17 & 46.51 \\
\hline 24. & Legal services & 2.20 & 1.09 & 8.66 & 0.10 \\
\hline 25. & Education services & 1.20 & 0.12 & 0.20 & 12.34 \\
\hline 26. & Social services & 2.06 & 0.53 & 0.71 & 17.59 \\
\hline 27. & Private households & 0.26 & 0.00 & 0.00 & 2.95 \\
\hline
\end{tabular}

1. These data are derived from unpublished BEA estimates. 


\section{Table 5}

\section{Distribution of Domestic Income within Private Nonagricultural Industries, by Legal Form of Organization, $1994^{1}$}

\begin{tabular}{|c|c|c|c|c|}
\hline & & Corporations & $\begin{array}{l}\text { Sole Proprietorships } \\
\text { and Partnerships }\end{array}$ & $\begin{array}{l}\text { Households and } \\
\text { Nonprofit Institutions }\end{array}$ \\
\hline 1. & TOTAL & 75.57 & 15.10 & 9.33 \\
\hline 2. & Mining & 84.50 & 15.50 & 0.00 \\
\hline 3. & Construction & 71.65 & 28.35 & 0.00 \\
\hline 4. & Manufacturing & 96.40 & 3.52 & 0.08 \\
\hline 5. & Durables & 97.10 & 2.88 & 0.02 \\
\hline 6. & Nondurables & 95.43 & 4.39 & 0.18 \\
\hline 7. & Transportation and utilities & 85.95 & 10.82 & 3.24 \\
\hline 8. & Transportation & 82.62 & 11.22 & 6.16 \\
\hline 9. & Communications & 87.34 & 11.82 & 0.84 \\
\hline 10. & Public utilities & 89.93 & 9.08 & 0.99 \\
\hline 11. & Trade & 87.78 & 12.14 & 0.08 \\
\hline 12. & Wholesale trade & 92.88 & 7.03 & 0.10 \\
\hline 13. & Retail trade & 84.21 & 15.72 & 0.07 \\
\hline 14. & Finance, insurance, and real estate ${ }^{2}$ & 41.91 & 13.86 & 5.76 \\
\hline 15. & Services & 49.88 & 25.03 & 25.10 \\
\hline 16. & Hotels and lodging & 68.72 & 30.62 & 0.66 \\
\hline 17. & Personal services & 50.24 & 49.76 & 0.00 \\
\hline 18. & Motion picturest & 58.72 & 41.28 & 0.00 \\
\hline 19. & Amusement & 57.81 & 26.66 & 15.53 \\
\hline 20. & Business and other & 73.63 & 23.95 & 2.42 \\
\hline 21. & Auto repair & 59.49 & 40.51 & 0.00 \\
\hline 22. & Miscellaneous repair & 64.67 & 35.33 & 0.00 \\
\hline 23. & Health services & 37.63 & 18.90 & 43.47 \\
\hline 24. & Legal services & 37.12 & 62.48 & 0.40 \\
\hline 25. & Education services & 7.21 & 2.63 & 90.16 \\
\hline 26. & Social services & 19.49 & 5.45 & 75.06 \\
\hline 27. & Private households & 0.00 & 0.00 & 100.00 \\
\hline
\end{tabular}

1. These data are derived from unpublished BEA estimates.

2. Finance, insurance, and real estate add to less than 100 because of the omission of owner-occupied housing. 


\section{Chart 1}

\section{Nonfarm Noncorporate Sector}
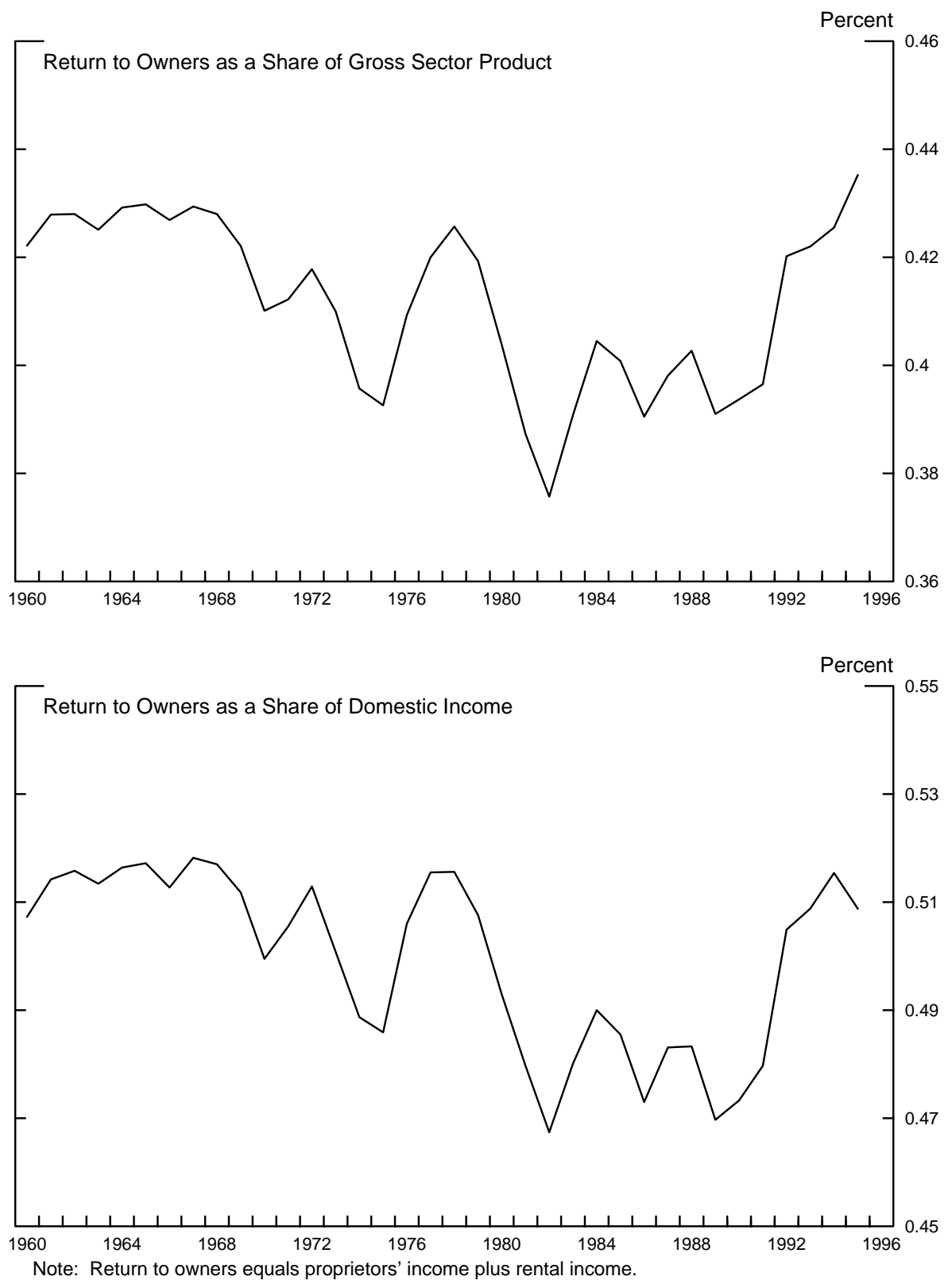


\section{Chart 2}

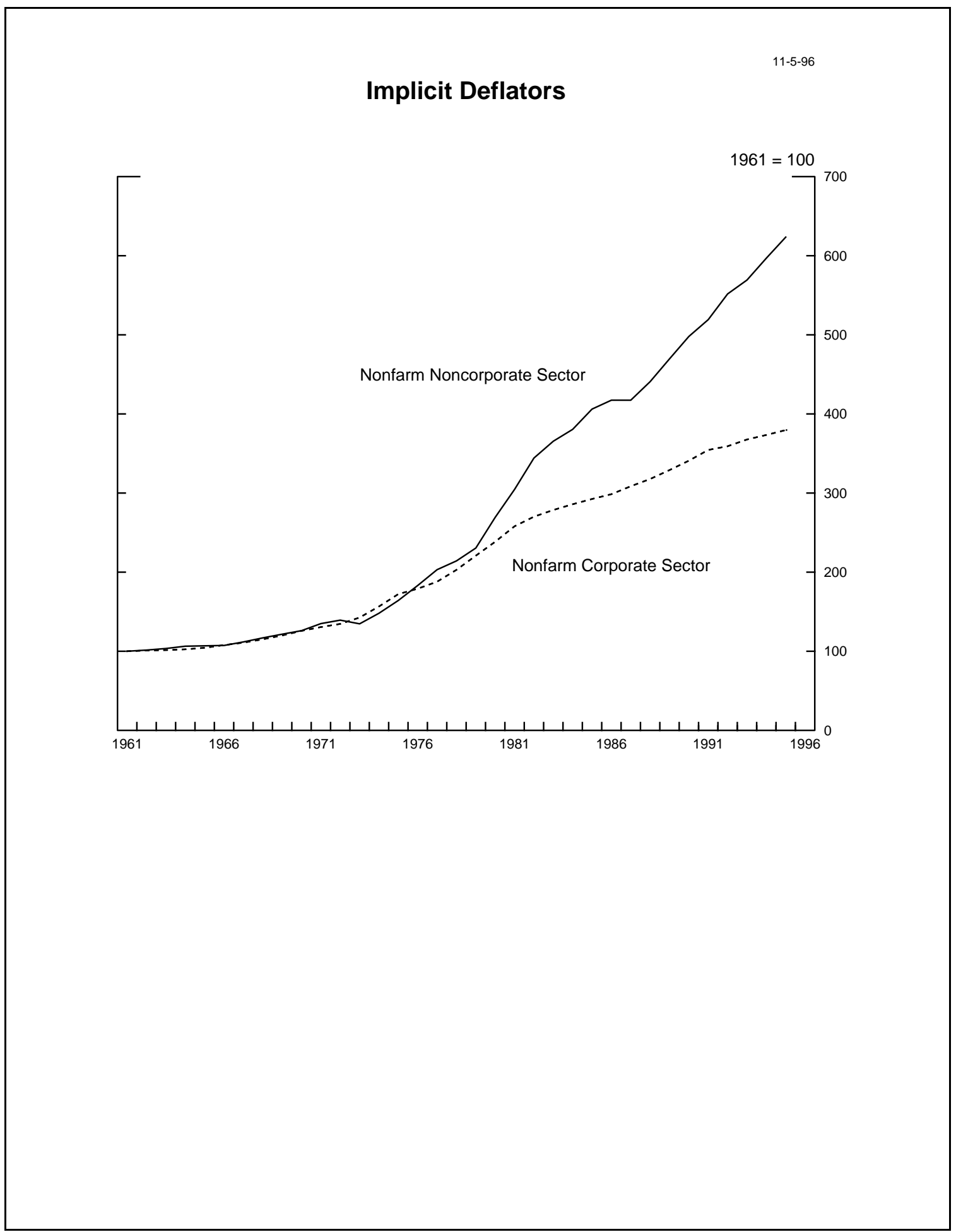




\section{Chart 3}

\section{Nonfinancial Corporations}

Price Indexes

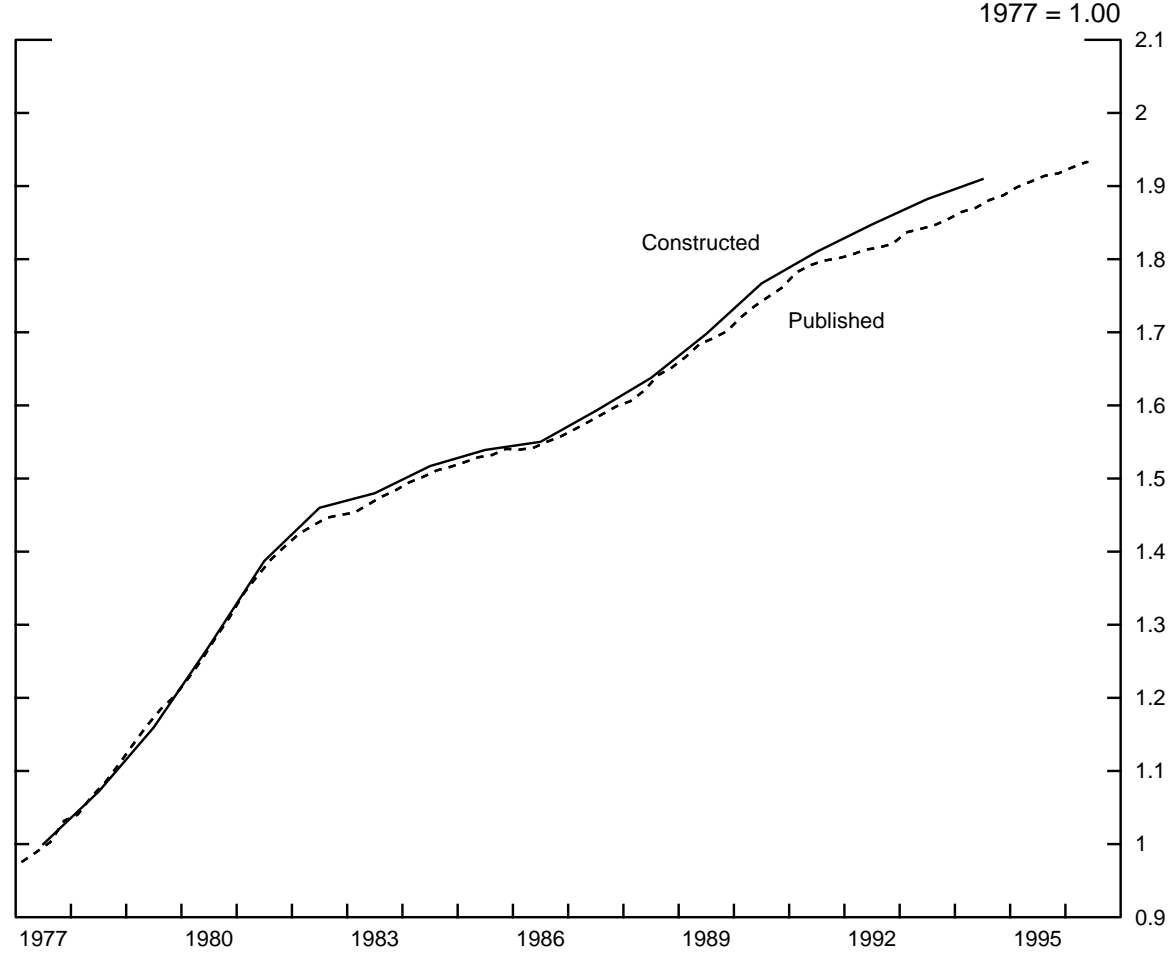

Note: BEA's published deflator for nonfinancial corporations is based on the implicit deflator for goods and structures. The constructed price measure is a Fisher index that weights two-digit GPO industry deflators by the corporate GPO for each industry. 


\section{Appendix 1}

\section{Detailed Description of the Sectoral Decomposition}

Table A-1 presents the 1996:Q2 levels of the data used in the sectoral decomposition. Columns A through I contain the series of primary interest; columns J through $Q$ contain the sectors needed to construct the series in the first nine columns. A description of the source data, accounting identity, or interpolation/exrapolation procedure used to construct each cell is given below.

Column A Nonfarm Business Less Housing, Product-based

Lines 1-11: Column J-Column O-Column P-Column Q. That is, the domestic business sector less the farm sector, owner-occupied housing, and the rental value of buildings and equipment owned by nonprofit institutions. The domestic business sector excludes output originating in private households, nonprofit institutions, and general government from total GDP.

Line 12: $\quad$ BLS. Hours of all persons in the nonfarm business sector.

Column B Nonfarm Business Less Housing, Income-based

Line 1: A1 - NIPA statistical discrepancy for gross domestic product (NIPA 1.9, line 15).

Line 2: $\quad \mathrm{B} 1 /(\mathrm{A} 1 / \mathrm{A} 2)$

Line 3: $\quad$ A3

Line 4: A4-(NIPA 1.9, line 15)

Line 5: $\quad$ A5-(NIPA 1.9, line 15)

Lines 6-12: A6 through A12

Column C Nonfarm Corporate Business

Lines 1-12: Column E+Column D

Column D Financial Corporations

Lines 1-12: Column K-Column L

Column E Nonfarm Nonfinancial Corporations

Lines 1-12: Column L-Column N

\section{Column F $\quad$ Manufacturing Corporations}

Line 1: $\quad$ F4+F3

Line 2: $\quad F 1 /($ manufacturing deflator). The manufacturing deflator is the implicit gross product originating (GPO) deflator interpolated and extrapolated to the quarterly frequency using a deflator for nonfarm goods (calculated using NIPAs 1.3 and 1.4, lines 4 and 5, and NIPAs 1.7 and 1.8, line 6). 
Line 3: $\quad$ NIPA 6.22C, line 11, interpolated and extrapolated by the capital consumption allowance for nonfinancial corporations.

Line 4: $\quad$ F5+F6

Line 5: $\quad$ M5*(F6/M6). This assumes that indirect business taxes, etc., for manufacturing corporations are proportional to their income relative to the income of all manufacturing business (column M).

Line 6: $\quad \mathrm{F} 7+\mathrm{F} 8+\mathrm{F} 9$

Line 7: $\quad \mathrm{M} 7 * 0.98$

Line 8: $\quad$ M8

Line 9: $\quad$ M9*0.97 (This ratio is based on unpublished BEA data by legal form of business.)

Lines 10-11: Not applicable

Line 12: $\quad$ BLS. Hours of all employees in manufacturing* 0.98 The 0.98 estimate for the corporate share of manufacturing hours is based on data provided by BEA for the distribution of labor compensation by legal form of organization and industry.

\title{
Column G Nonfarm Nonmanufacturing Corporations
}

Lines 1-12: Column E-column F. Note, line 2 is adjusted to take account of the residual that emerges from chain weight aggregation.

\section{Column $\mathrm{H} \quad$ Nonfarm Noncorporate Business}

Lines 1-12: Column A-column D-column E. Note, line 2 is adjusted to take account of the residual that emerges from chain weight aggregation.

\section{Column I Nonfarm Noncorporate Business, Income-based}

Lines 1-12: Column B-column D-column E. Note, line 2 is adjusted to take account of the residual that emerges from chain weight aggregation.

\author{
Column J Domestic Business \\ Line 1: $\quad$ NIPA 1.7, line 2. \\ Line 2: $\quad$ NIPA 1.8 , line 2. \\ Line 3: $\quad$ NIPA 1.9, line 6+line 11. \\ Line 4: J1-J3. \\ Line 5: $\quad$ NIPA 3.1, line 4+NIPA 1.9, line 14+NIPA 1.9, line 15-NIPA 3.2, \\ line 25 \\ Line 6: J4-J5. \\ Line 7: $\quad$ NIPA 1.14, line 2 - NIPA 3.7B, line 38 - NIPA 1.7, line 7 - NIPA \\ 1.15 , line 49 . (The last item, rest of world compensation, is linearly \\ interpolated to the quarterly frequency.) \\ Line 8: $\quad$ NIPA 1.16, line 9. \\ Line 9: J6-J7-J8-J10-J11 \\ Line 10: $\quad$ NIPA 1.14, line 9. \\ Line 11: $\quad$ NIPA 1.14, line 17. \\ Line 12: BLS. Hours of all persons in the business sector.
}




\title{
Column K Corporations \\ Line 1: $\quad$ NIPA 1.16, line 1 \\ Line 2: $\quad$ NIPA 1.16, line 36+(NIPA 1.16, line 18/financial deflator). The financial deflator is the implicit GPO deflator for banking, credit agencies other than banks, insurance carriers, and security and commodity brokers interpolated and extrapolated by the quarterly deflator for personal consumption expenditures on brokerage and bank service charges, services furnished without payment by financial intermediaries, and the expense of handling life insurance (NIPA 2.4, lines 61-64). \\ Lines 3-9: $\quad$ NIPA 1.16, lines 2, 3, 4, 5, 6, 9, and 17. \\ Lines 10-11: Not applicable. \\ Line 12: $\quad \mathrm{L} 12$ + (financial hours). The financial hours are calculated from BLS data on hours paid in the finance, insurance and real estate industry, excluding hours in SIC 64, 65, and 67, reduced by 6 percent to adjust for hours worked vs. hours paid. (This series is similar to BEA's annual series on employee hours for SICs 60, 61, and 63.)
}

\section{Column L Nonfinancial Corporations}

Lines 1-9: $\quad$ NIPA 1.16, lines 19, 36, 20-24, 27, and 35.

Lines 10-11 Not applicable.

Line 12: BLS. Hours of all employees in the nonfinancial corporate sector.

\author{
Column M Manufacturing \\ Line 1: $\quad$ M3+M4 \\ Line 2: $\quad \mathrm{M} 1 /$ (manufacturing deflator) (see F2). \\ Line 3: $\quad$ NIPA 6.13C, line 7 + NIPA 6.22C, line 11, interpolated and \\ extrapolated by the capital consumption allowance for nonfinancial \\ corporations. \\ Line 4: $\quad$ M5+M6 \\ Line 5: $\quad$ GPO data. Indirect business taxes are interpolated and extrapolated \\ by manufacturing shipments; business transfers and subsidies are \\ interpolated to the quarterly frequency using a cubic spline. \\ Line 6: $\quad$ M7+M8+M9+M10 \\ Line 7: $\quad$ NIPA 2.1, line $5+$ (NIPA 6.2C, line 13 - NIPA 6.3C, line 13), \\ interpolated and extrapolated by NIPA 1.16, line 26 (supplements \\ for all nonfinancial corporations). \\ Line 8: $\quad$ NIPA 6.16C, line 14 (adjusted to be consistent with latest GPO \\ figures). \\ Line 9: $\quad$ NIPA $6.15 \mathrm{C}$, line 6, interpolated and extrapolated by NIPA 1.16, \\ line 35. \\ Line 10: $\quad$ NIPA $6.12 \mathrm{C}$, line 5, interpolated and extrapolated by manufacturing \\ shipments. \\ Line 11: $\quad$ Not applicable. \\ Line 12: $\quad$ BLS. Hours of all persons in manufacturing.
}




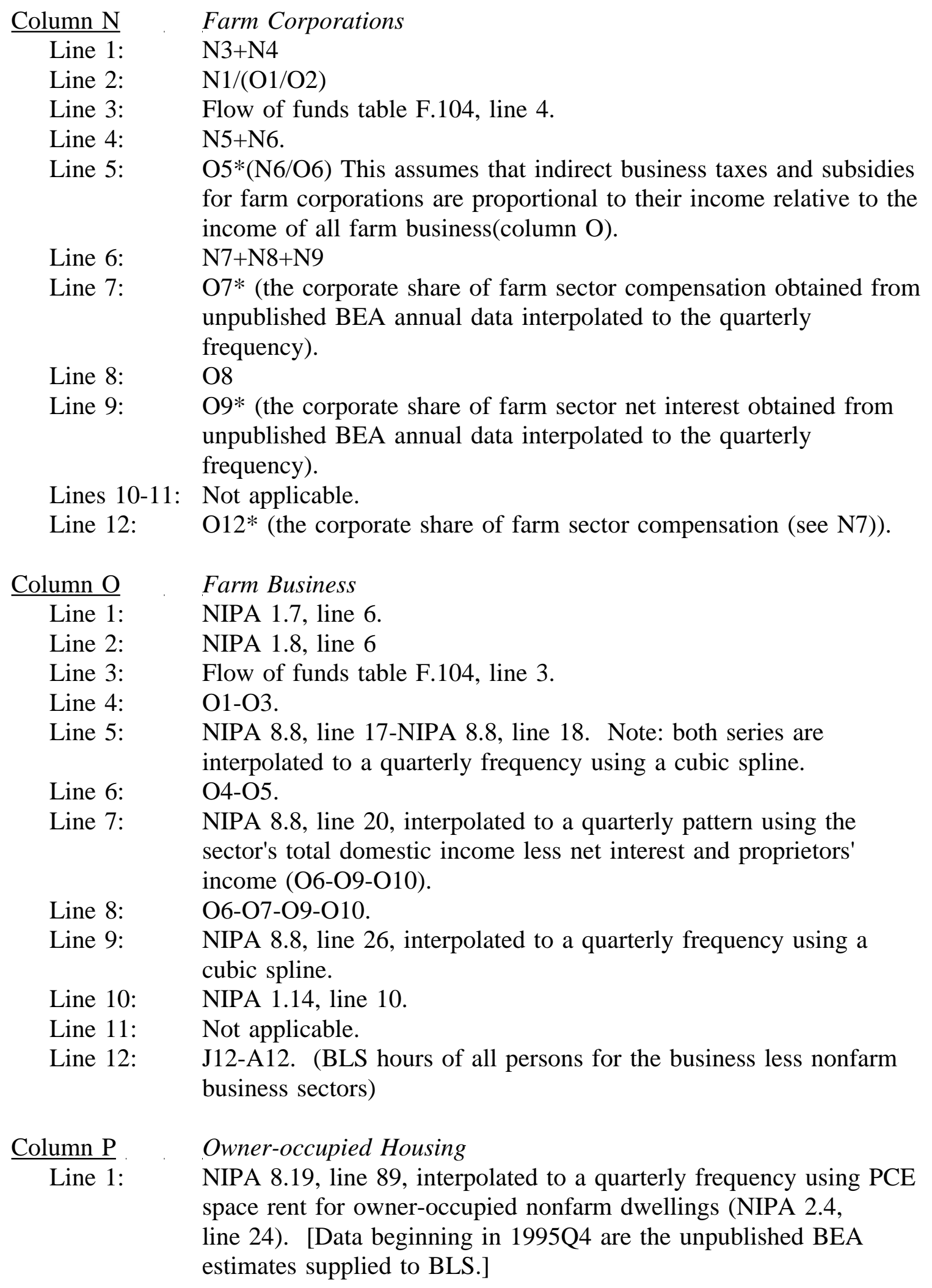


Line 2: $\quad$ P1 deflated by the implicit deflator for nonfarm housing product (NIPA 1.7, line 5/NIPA 1.8, line 5). [Data beginning in 1995Q4 are the unpublished BEA estimates supplied to BLS.]

Line 3: $\quad$ NIPA 8.19, line 90, interpolated to a quarterly frequency using the consumption of fixed capital for the noncorporate sector (NIPA 1.9, line 6-NIPA 1.14, line 33).

Line 4: $\quad$ P1-P3.

Line 5: $\quad$ P4-P6.

Line 6: $\quad \mathrm{P} 9+\mathrm{P} 11$

Lines 7-8: Not applicable.

Line 9: $\quad$ NIPA 8.19, line 93, interpolated to a quarterly frequency using net interest for the noncorporate sector (NIPA 1.9, line 19-NIPA 1.16, line 17).

Line 10: $\quad$ Not applicable.

Line 11: $\quad$ NIPA 8.19, line 94, interpolated to a quarterly frequency using rental income of persons (NIPA 1.14, line 17).

Line 12: $\quad$ Not applicable.

Column Q Building and Equipment Serving Nonprofit Institutions

Line 1: $\quad$ NIPA 8.19, line 102, interpolated to a quarterly frequency using nonfarm business output less housing (NIPA 1.7, line 4). Note: this is the convention used by BLS.

Line 2: $\quad$ Q1 deflated by the implicit deflator for nonfarm business output less housing (NIPA 1.7, line 4/NIPA 1.8, line 4).

Line 3: $\quad$ NIPA $8.19,103$, interpolated to a quarterly frequency using the consumption of fixed capital for the noncorporate sector (NIPA 1.9, line 6-NIPA 1.14, line 33).

Line 4: Q1-Q3.

Line 5: $\quad$ Q6-Q4.

Line 6: $\quad$ Q9

Lines 7-8: $\quad$ Not applicable.

Line 9: $\quad$ NIPA 8.19 , line 105, interpolated to a quarterly frequency using net interest for the noncorporate sector (NIPA 1.9, line 19-NIPA 1.16, line 17).

Lines 10-12: Not applicable. 
Table A-1

Sectoral Decomposition of Gross Product and Income -- 1996:Q2

\begin{tabular}{|c|c|c|c|c|c|c|c|c|c|c|}
\hline & & $\begin{array}{c}\text { Nonfarm } \\
\text { Bus. less } \\
\text { housing, } \\
\text { product } \\
\text { based }\end{array}$ & $\begin{array}{c}\text { Nonfarm } \\
\text { Bus. less } \\
\text { housing, } \\
\text { income } \\
\text { based }\end{array}$ & $\begin{array}{l}\text { Nonfarm } \\
\text { corporate } \\
\text { business }\end{array}$ & $\begin{array}{l}\text { Financial } \\
\text { Corps. }\end{array}$ & $\begin{array}{l}\text { Nonfarm } \\
\text { Non- } \\
\text { financial } \\
\text { corps. }\end{array}$ & $\begin{array}{l}\text { Mfg. } \\
\text { corps. }\end{array}$ & $\begin{array}{l}\text { Nonfarm } \\
\text { Non- } \\
\text { manufac- } \\
\text { turing } \\
\text { corps. }\end{array}$ & $\begin{array}{l}\text { Nonfarm } \\
\text { Non- } \\
\text { corporate, } \\
\text { product } \\
\text { based }\end{array}$ & $\begin{array}{l}\text { Nonfarm } \\
\text { Non- } \\
\text { corporate, } \\
\text { income } \\
\text { based }\end{array}$ \\
\hline & & A & B & C & D & $E$ & $\mathrm{~F}$ & G & $\mathrm{H}$ & I \\
\hline 1 & Gross product: nominal & 5714.4 & 5771.9 & 4552.5 & 484.0 & 4068.5 & 1242.2 & 2826.3 & 1161.9 & 1219.4 \\
\hline 2 & Gross product: $\$ 92$ & 5256.9 & 5309.8 & 4247.7 & 427.4 & 3819.9 & 1187.8 & 2631.9 & 1016.9 & 1065.4 \\
\hline 3 & Cons. of fixed cap & 601.8 & 601.8 & 468.8 & 31.1 & 437.7 & 152.6 & 285.1 & 132.9 & 132.9 \\
\hline 4 & Net dom. product & 5112.6 & 5170.1 & 4083.7 & 452.9 & 3630.8 & 1089.6 & 2541.2 & 1029.0 & 1086.5 \\
\hline 5 & IBT+Bus. trans.-subs. & 429.0 & 486.5 & 450.3 & 47.3 & 403.0 & 62.8 & 340.3 & -21.3 & 36.2 \\
\hline 6 & Domestic income & 4683.6 & 4683.6 & 3633,3 & 405.5 & 3227.8 & 1026.8 & 2201.0 & 1050.2 & 1050.2 \\
\hline 7 & Compensation & 3320.9 & 3320.9 & 2938.2 & 241.9 & 2696.3 & 830.6 & 1865.7 & 382.8 & 382.8 \\
\hline 8 & Profits w/IVA\&CCA & 574.7 & 574.7 & 574.7 & 143.5 & 431.2 & 161.5 & 269.7 & & \\
\hline 9 & Net interest & 253.6 & 253.6 & 120.4 & 20.1 & 100.3 & 34.8 & 65.5 & 133.2 & 133.2 \\
\hline 10 & Prop. income & 469.4 & 469.4 & & & & & & 469.4 & 469.4 \\
\hline 11 & Rental income & 65.0 & 65.0 & & & & & & 65.0 & 65.0 \\
\hline 12 & Hours of persons & 173.8 & 173.8 & 133.5 & 8.1 & 125.3 & 35.4 & 89.9 & 40.4 & 40.4 \\
\hline
\end{tabular}

\begin{tabular}{|c|c|c|c|c|c|c|c|c|c|}
\hline & & $\begin{array}{l}\text { Domestic } \\
\text { business }\end{array}$ & $\begin{array}{l}\text { Corp- } \\
\text { orate } \\
\text { (Total) }\end{array}$ & $\begin{array}{c}\text { Non- } \\
\text { financial } \\
\text { corps. } \\
\text { (Total) }\end{array}$ & $\begin{array}{l}\text { Mfg. } \\
\text { (Total) }\end{array}$ & $\begin{array}{l}\text { Farm } \\
\text { corps. }\end{array}$ & $\begin{array}{l}\text { Farm } \\
\text { (Total) }\end{array}$ & $\begin{array}{c}\text { Owner- } \\
\text { occupied } \\
\text { housing }\end{array}$ & $\begin{array}{l}\text { Rental } \\
\text { value of } \\
\text { buildings } \\
\text { and } \\
\text { equip. of } \\
\text { non- } \\
\text { profits }\end{array}$ \\
\hline & & $\mathrm{J}$ & $\mathrm{K}$ & L & M & N & $\mathrm{O}$ & $P$ & Q \\
\hline 1 & Gross product: nominal & 6334.6 & 4565.6 & 4081.6 & 1298.3 & 13.1 & 97.6 & 476.5 & 46.2 \\
\hline 2 & Gross product: $\$ 92$ & 5807.3 & 4258.4 & 3831.0 & 1241.4 & 11.1 & 82.8 & 425.1 & 42.5 \\
\hline 3 & Cons. of fixed cap & 726.4 & 471.0 & 439.9 & 159.7 & 2.2 & 23.5 & 78.0 & 23.2 \\
\hline 4 & Net dom. product & 5608.2 & 4094.6 & 3641.7 & 1138.6 & 10.9 & 74.1 & 398.5 & 23.0 \\
\hline 5 & IBT+Bus. trans.-subs. & 552.8 & 450.3 & 403.0 & 65.6 & -0.0 & -0.1 & 114.4 & 9.4 \\
\hline 6 & Domestic income & 5055.4 & 3644.3 & 3238.8 & 1073.0 & 11.0 & 74.2 & 284.1 & 13.5 \\
\hline 7 & Compensation & 3336.9 & 2945.3 & 2703.4 & 847.5 & 7.1 & 16.0 & & \\
\hline 8 & Profits w/IVA\&CCA & 577.3 & 577.3 & 433.8 & 161.5 & 2.6 & 2.6 & & \\
\hline 9 & Net interest & 501.5 & 121.6 & 101.5 & 35.9 & 1.2 & 9.9 & 224.5 & 13.5 \\
\hline 10 & Prop. income & 515.2 & S & & 28.2 & 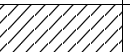 & 45.8 & & \\
\hline 11 & Rental income & 124.5 & & & & & 131 & 59.5 & 3 \\
\hline 12 & Hours of persons & 178.6 & 135.6 & 127.4 & 37.1 & 2.1 & 4.7 & & \\
\hline
\end{tabular}

